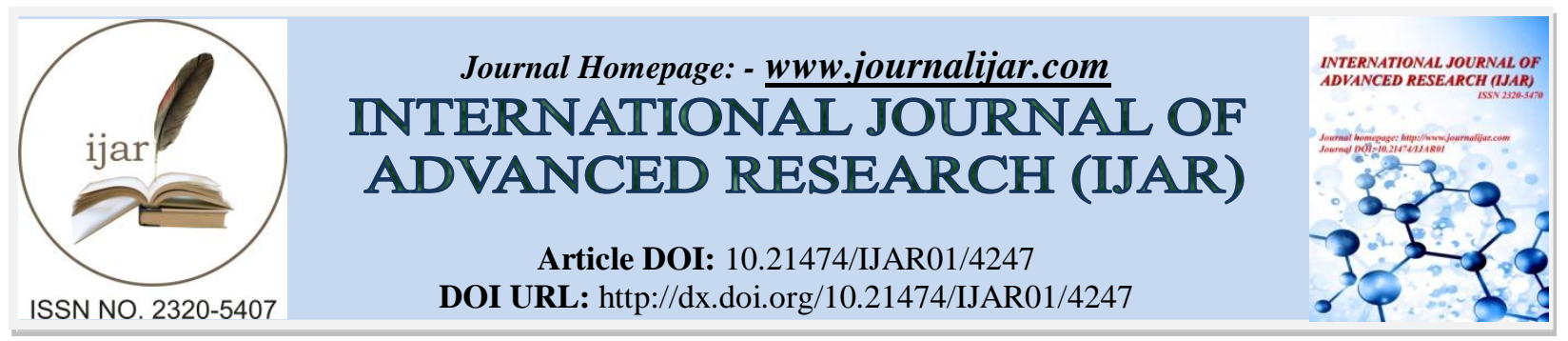

RESEARCH ARTICLE

\title{
ANTIMICROBIAL ACTIVITY OF ALKALOID EXTRACT FROM THE LEAVES OF ZYGOPHYLLUM FABAGO.
}

Fahem M. Mahmood.

Department of Pathology, College of Medicine, Al-Nahrain University.

\section{Manuscript Info}

Manuscript History

Received: 24 March 2017

Final Accepted: 26 April 2017

Published: May 2017

Key words:-

Antimicrobial, Zygophyllum fabago,

Alkaloid extract, Sick building.

\section{Abstract}

Due to the risk properties of commercial biocides, plant-based biocides may proposal a safer alternative for control microbes that cause sick building syndrome and building deterioration. The aim of the study was to determine a new source of bioactive extracts from plants. Alkaloid extract from leaves of Zygophyllum fabago, was screened for potential antimicrobial activity against one species of bacteria (Bacillus subtilis) and four filamentous fungi (Aspergillus flavus, Aspergillus niger, Penicillium oxalicum and Cladosporium oxysporum) isolated from enclosed sick buildings. The minimum inhibitory concentration against the highly sensitive microorganisms i.e. B. subtilis and P. oxalicum was 0.157 and $0.635 \mathrm{mg} / \mathrm{ml}$, respectively.

Copy Right, IJAR, 2017,. All rights reserved.

\section{Introduction:-}

Microbes, mostly fungi and bacteria; on building materials and indoor surfaces represents indoor air quality problems (Chester and Levine, 1997; Zhu et al., 2004). Species of fungi and bacteria have been isolated from indoor damaged building materials (Hyvärinen et al., 2002). These organisms were caused odour, defacement and deterioration to the building materials (Srikanth et al., 2008). Many of these microorganisms were related to allergic and irritant reactions, infectious disease respiratory problems, hypersensitivity reactions, cancer and leukemia on the building residents (Green and Scarpino, 2002).; (Burge, 2004).

Controlling of these microorganisms using active materials such as synthetic biocides has been limited due to their harmful effects on the environments, deposit problems and their carcinogenicity (Verma et al., 2008). Thus, the search for ways to control and treatment the effects of microbes in an eco-friendly way is a need. Therefore, biocides derived from plants represents a safer, more active and environment-friendly alternatives for microbial control because they are rich in bioactive phytochemicals (Cooley et al., 1998).

Zygophyllum fabago belongs to the family Zygophyllaceae, order Geramiales (Bhattacharyya and Johri, 1998), commonly called Bean-Coped or Syrian bean-caper (Jose-Abod et al., 2007), is a sub-shrub distributed in tropical and sub-tropical region in south Europe, North Africa and West-South Asia including Iraq (Al-Mokhtar, 1971). Z. fabago extract is used as antitussive, expectorant, anti-inflammatory and for removing pains (Feng et al., 2008). It is also used as a part of drug for rheumatism and goat; also used extremely as poultice to cure skin diseases, external wound and injuries (Khan et al., 2014). Many researches showed about antimicrobial activity of $Z$. fabago against bacteria and fungus but by using crude extract (Zaidi and Crow, 2005; (Dana et al., 2010; Mohammed et al., 2013; 
Abdel-Hamid, 2014).). In this study we test a new source of plant-based preparations, available in our environment and examine fractionation compounds (Alkaloids) for remediation of microbial aerosols.

\section{Materials and Methods:- Plant Material:-}

Zygophyllum fabago leaves were collected in Baghdad in June 2016. The botanical identification was made by comparing with authentic herbarium specimen at the herbarium of Botanical Garden in Department of Biology, College of Education for Pure Science (Ibn Al-Haitham), University of Baghdad.

\section{Source of Microorganisms:-}

Four species of filamentous fungi and one species of Gram-positive bacteria isolated during a series of indoor samplings in air-conditioned sick buildings Wardah et al. (2011) were obtained from the culture collection unit of the Plant Pathology Laboratory, School of Biological Sciences, Universiti Sains Malaysia. The microorganisms were identified as Aspergillus flavus (AP22BA), A. niger (AP29BA). Penicillium oxalicum (PP1BA), Cladosporium oxysporum (CP1BA) and Bacillus subtillus (BP1BA) and kept in $15 \%$ glycerol at $-86{ }^{\circ} \mathrm{C}$ (Salleh and Sulaiman, 1984).). The work cultures of bacterium and fungi were maintained at $4{ }^{\circ} \mathrm{C}$ on Nutrient Agar (NA) and Potato Dextrose Agar (PDA) slants, respectively.

\section{Extraction and Isolation:-}

The crude alkaloidal extracts from the plants were obtained according to the method of Harborne (1984) and (Zaree et al., 2013) with slight modifications. Dried and powdered leaves of Z. fabago $(1.5 \mathrm{~kg})$ were extracted with $80 \%$ ethanol in a Soxhlet apparatus and concentrated to a dark brown gummy residue (349.5 g). The extract was then treated with $5 \%$ aqueous HCL to $\mathrm{pH}$ and extracted with $\mathrm{CHCl}_{3}(3 \mathrm{X} 800 \mathrm{ml})$. Next, the aqueous phase was basified to $\mathrm{pH}-10$ with $25 \% \mathrm{NH}_{4} \mathrm{OH}$ and extracted repeatedly with $\mathrm{CHCL}_{3}(3 \mathrm{X} 800 \mathrm{ml})$. The alkaline solution remaining after removal of $\mathrm{CHCl}_{3}$ fraction was treated with an excess of Mayer's reagent until precipitation ceased . The resulting precipitate was filtered by suction, washed with water, dissolved in $100 \mathrm{ml}$ methanol and passed through a column of anion exchange resin $(\mathrm{Cl})$ which was preconditioned before use with $5 \% \mathrm{HCl}$. The column was then rinsed with $500 \mathrm{ml}$ methanol and the column eluent and rinsing were combined to afford a residue of crude quaternary alkaloid chloride fraction $(1.529 \mathrm{~g})$. Thin-layer chromatography of this fraction revealed the presence of one spot (Rf 0.54) (Henrickson et al., 1997).

\section{Antimicrobial activity test:-}

The antimicrobial activity was carried out by disc diffusion method Murray et al. (1995) with a slight modification in volume and concentration of tested compound. Briefly, $0.1 \mathrm{ml}$ of suspension containing of $10^{8} \mathrm{CFU} / \mathrm{ml} \mathrm{of}$ bacterium and $10^{4}$ spore/ml of fungi spread on Nutrient Agar and potato dextrose agar (peeled potato $250 \mathrm{~g}$, dextrose $20 \mathrm{~g}$, agar $15 \mathrm{~g}$, distilled water 1 liter), respectively. Sterilized Whatman AA discs containing $20 \mu 1$ of tested compound $(100 \mathrm{mg} / \mathrm{ml}$ in DMSO) were placed into the inoculated agar. The quantity of compound was $2 \mathrm{mg} / \mathrm{disc}$. Equal volume of DMSO was assayed as negative control. The sample was tested against each organism in triplicate. The plates were incubated at room temperature $\left(28 \pm 2{ }^{\circ} \mathrm{C}\right)$ for $28 \mathrm{~h}$ in case of bacterium and $3-5$ days for fungi. The diameters of inhibition zones around discs were measured using ruler and expressed in millimeter ( $\mathrm{mm}$ ) unit.

\section{Determination of Minimum Inhibitory Concentration (MIC):-}

The minimum inhibitory concentration of the active compound against the highly sensitive microorganisms i.e. $B$. subtilis and $P$. oxalicum were determined by agar dilution method (Mukherjee, 2002).) with a slight modification. In treated plates, the amount of the compound was dissolved in $1 \mathrm{ml}$ sterile distilled water and then mixed thoroughly with $9 \mathrm{ml}$ of molten agar at $50{ }^{\circ} \mathrm{C}$ in pre-labeled sterile Petri dishes to obtain a series of final concentrations of compound between $0.625-0.0097 \mathrm{mg} / \mathrm{ml}$ for B. subtilis and $5-0.312 \mathrm{mg} / \mathrm{ml}$ for $P$. oxalicum. A control with sterile distilled water was also set up. About $20 \mu \mathrm{l}$ of suspension containing previously $10^{8} \mathrm{CFU} / \mathrm{ml}$ of bacterium and $10^{4}$ spore $/ \mathrm{ml}$ of fungi was used to inoculate the plates. The plates were then incubated at room temperature $(28 \pm$ $2^{\circ} \mathrm{C}$ ) for $48 \mathrm{~h}$ in case of $B$. subtilis and $72 \mathrm{~h}$ for $P$. oxalicum. The lowest concentration of the compound at which there was no visible growth of a microorganism after incubation was taken as MIC (Banso and Adeyemo, 2006).).

\section{Statistical Analysis:-}

Data analyzed with SPSS software to know the difference among the microorganisms. All determinations were made in triplicates and the data is reported as mean $\pm \mathrm{SE}$ for $(\mathrm{n}=3)$. Analysis of Variance (ANOVA) method was used for statistical analysis and at probability levels $(0.05,0.01,0.001)$ for the purpose of evaluating the differences 
in the results of transactions in terms of being significant (influence of material) or not significant differences (as a result of laboratory errors) (SAS., 2012).

\section{Results and Discussion:-}

Z. fabago leaves extract, showed a positive test results (orange sediment) with Dragendorff's reagent, this finding agree with Mohammed et al. (2013); Abdel-Hamid (2014); Sabahi et al. (1985) and Torssel (1997) which mentioned presented alkaloid compound in Z. fabago leaves. Abdel-Hamid (2014) determined the amount of alkaloids in leaves of Z. fabogo in about $0.44 \%$ from the total contents while in this study the amount of alkaloids extract was approximately $0.102 \%$, this different in amount may due to the variation of area of isolation, season and time of collecting (Jayanthy et al., 2013).

The alkaloid extract was tested against one species of bacteria (B. subtilis) and four filamentous fungi (A. flavus, A. niger, $P$. oxalicum and $C$. oxysporum) that were isolated from sick enclosed buildings and showed a significant effectiveness in which the level of probability was less than $(0.001,0.05,0.01)$. Using the simple disc diffusion assay, this compound exhibited zones of inhibition of at least $14.35 \pm 0.43 \mathrm{~mm}$ diameter against all the microorganisms at a loading of $2 \mathrm{mg} / \mathrm{disc}$ (Table 1 ).

Table I:- The diameter of inhibition zones of the isolated alkaloid.

\begin{tabular}{|c|c|c|c|c|c|}
\hline & \multicolumn{3}{|c|}{ Diameter of inhibition zone (mm)* } & \\
\hline & B. subtilis & $\begin{array}{c}\text { A. } \\
\text { niger }\end{array}$ & $\begin{array}{c}\text { A. } \\
\text { flavus }\end{array}$ & C. oxysporum & P. oxalicum \\
\hline Isolated alkaloid & $24.69 \pm 0.50$ & $14.35 \pm 0.43$ & $15.34 \pm 0.05$ & $15.66 \pm 0.21$ & $16.68 \pm 0.33$ \\
\hline
\end{tabular}

* refers to inhibition zone including the diameter of disk paper $(6 \mathrm{~mm})$.

Values are mean inhibition $(\mathrm{mm}) \pm$ S.E. of three replicate.

The minimum inhibitory concentration (MIC) values of this compound were also determined against the highly sensitive microorganisms i.e. B. subtilis and P. oxalicum using agar dilution method. The results (Table 2) showed that this compound was the most potent against $B$. subtilis with MIC of $0.157 \mathrm{mg} / \mathrm{ml}$.

Table II:- MIC values $\mathrm{mg} / \mathrm{ml}$ of the isolated alkaloid

\begin{tabular}{|l|c|c|}
\hline \multirow{2}{*}{} & \multicolumn{2}{|c|}{ MIC (mg/ ml) } \\
\cline { 2 - 3 } & Bacillus subtilis & Penicillium oxalicum \\
\hline Isolated alkaloid & 0.157 & 0.635 \\
\hline
\end{tabular}

The results showed that the treatment of fungi, Aspergillus niger, Aspergillus flavus, Caldosporium oxysporum and Penicillium oxalicum and bacteria Bacillus subtilis with Z. fabago alkaloids extract have antimicrobial activity in which the level of probability was less than $(0.001,0.05,0.01)$. This results agreed with Zaidi and Crow (2005) which found that the methanolic extracts of $Z$. fabago have a highly effect against Candida albicans (Fungus) and Escherichia coli (Bacteria), and agreed with Dana et al. (2010) who mentioned that there was an inhibitory effect of aqueous extracts of $Z$. fabago leaves on two plant phytopathogenic fungal species (Fusarium oxyosporum $\mathrm{f}$. sp. melonis and Pythium aphanidermatum) which were studied under laboratory conditions, the maximum mean inhibition was recorded with the $10 \%$ w/v extracts was $42.9 \%$ and $85.3 \%$, respectively. Moreover, the cytotoxicity of $Z$. fabago leaves extract was observed against $C$. albicans at different concentrations of extracts for a period of 1 , 2, and $24 \mathrm{~h}$ at $25^{\circ} \mathrm{C}$, the $1 \mathrm{~h}$ exposure showed that $1.0 \mathrm{~g} / \mathrm{ml}$ extract of $Z$. fabago killed $98 \%$ of cells (Zaidi and Crow, 2012). Study Mohammed et al. (2013) found that the aqueous and alcoholic extracts of Z. fabago leaves have antimicrobial activity against eight species of pathogenic bacteria (Escherichia coli, Klebsilla Pneumonia, Proteus vulgaris, Proteus mirabilis, Salmonella sp., Pseudomonas aeruginosa, Streptococcus Pyogens, Staphylococcus aureus) with six different concentration began with $40 \mathrm{mg} / \mathrm{ml}$ to $100 \mathrm{mg} / \mathrm{ml}$ by using agar well diffusion method which showed that alcoholic extracts was effective than aqueous ones and that both Staphylococcus aureus and Escherichia coli were the most affected species.

Results showed that the effectiveness of extracts were varied according to microorganisms, extracts were more effective against bacteria B. subtilis. This founding agree with Gnan and Sheriha (1986) which showed that the sensitivity of bacteria B. subtilis and $S$. aureus to alkaloids was more than other organisms. This inhibitory action can be explained by interaction of alkaloids with metabolic reactions necessary to growth and reproduction of 
microorganisms by inhibition protein synthesis at levels of ribosome and distraction component of plasma membrane (lipid and protein) (Okoye, 2015).

Z. fabago contains two type from alkaloids (indole derivatives and anthranilic acid derivatives), the first type effect on amino acid glysine whereas the second type effect on RNA and DNA synthesis and inhibits of protein synthesis in addition to inhibition of ionic carriers and canal (Wink, 1997). In fungus, alkaloids inhibit chitin synthesis and sterol that are important in synthesis of fungus cell wall by inhibition of important synthesis wall enzyme like Sterol $\Delta^{23}$-methyltrnferase and Chitin synthase (Kang et al., 1999).

\section{Conclusion:-}

In summary, the current study together with previous results are a significant step in developing plant-based microbial biocides which are eco-friendly in treatment airborne aerosols and consequently to be established commercially.

\section{References:-}

1. Abdel-Hamid R. A. (2014). Investigation of chemical constituents and biological activities of some native halophytes, Doctor of Philosophy (PhD), Al-Farabi Kazakh National University, Republic of Kazakhstan, Almaty: $147 \mathrm{pp}$.

2. Al-Mokhtar J.A.H. (1971). Zygophyllaceae of Iraq (taxonomy and economic important). Ministry of Agriculture of the Republic of Iraq, Abu Graib: 35 pp.

3. Banso A. and Adeyemo S. (2006). Phytochemical screening and antimicrobial assessment of Abutilon mauritianum, Bacopa monnifera and Datura stramonium. Biokemistri, 18: 39-44.

4. Bhattacharyya B. and Johri B. M. (1998). Flowering Plants Taxonomy and Phylogeny, S. Springer Verlag, Berlin, Heidelberg, New York: 753 pp.

5. Burge P. (2004). Sick building syndrome. Occup. Environ. Med., 61: 185-190.

6. Chester A. and Levine, P. (1997).The natural history of concurrent Sick Building Syndrome and Chronic Fatigue Syndrome. J. Psych. Res., 31(1): 51-57.

7. Cooley J., Wong W., Jumper C. and Straus D. (1998). Correlation between the prevalence of certain fungi and sick building syndrome. Occup. Environ. Med., 55: 579-584.

8. Dana E. D., Delomas J. G. and Sanchez J. (2010). Effects of the aqueous extracts of Zygophyllum fabago on the growth of Fusarium oxyosporum f. sp. melonis and Pythium aphanidermatum. Weed Biol. Manag., 10: 170175.

9. Feng Y. L., Wu B., Li H. R., Li Y. Q., Xu L. Z., Yang S. L. and Kitanaka S. (2008). Triterpenoidal saponins from the barks of Zygophyllum fabago L. Chem. Pharm. Bull., 56: 858-860.

10. Gnan S.O. and Sheriha G.M. (1986). Antimicrobial activity of (+) - turbine,” J. Food Protec., 49 (5): 340-341.

11. Green C.F. and Scarpino P.V. (2002). The use of ultraviolet germicidal irradiation (UVGI) in disinfection of airborne bacteria. Environ. Engin. and Pol., 3:101-107.

12. Harborne J.B. (1984). Phytochemical methods. 2. New York: Chapman and Hall;

13. Henrickson C.H., Byrd L.C. and Hunter N. W. (1997). A laboratory for general, organic and biochemistry, $2^{\text {nd }}$. WCB/ McGraw-Hill.

14. Hyvärinen A., Meklin, T., Vepsäläinen, A. and Neralainen, A. (2002). Fungi and actinobacteria in moisture damaged building materials-Concentrations and diversity. Int. Biodeteriorat. and Biodegrad., 49:27-37.

15. Jayanthy A., Prakash K. U. and Remashree A. B. (2013). Seasonal and Geographical Variations in Cellular Characters and Chemical Contents in Desmodium gangeticum (L.) DC. An Ayurveda Medicinal Plant. Int. J. Herbal Med. 1 (1): 34-37.

16. Jose-Abod M., Ansuategui M. and Bermejo, P. (2007). Active antifungal substances from natural source. ARKivoc, vii: 116-145.

17. Kang S.P., Kab C.K., Jai H. K., Adams D.J., Jung T.N. and Yong K.P. (1999). Differential inhibitory effects of protobeer beeriness on sterol and chitin biosynthesis in Candida albicans. J. Antimicrob. Chemother., 34: 667674.

18. Khan S.S., Khan, A. Khan, A. Wadood, A., Farooq U., Ahmed, A., Zahoor A., Ahmad V.U., Sener B. and Erdemoglu N., (2014). Urease inhibitory activity of ursane type sulfated saponins from the aerial parts of Zygophyllum fabago Linn. Phytomedicine, 21(3): 379-382.

19. Mohammed N. T., Zeki L. S. and Majeed I. A. (2013). Antibacterial activity of Zygophllum fabago L. Leaves extracts. J. Al-Nahrain Univ., 16 (2): 163-166. 
20. Mukherjee B. K. (2002). Quality control herbal drugs and approach to evaluation of botanicals, New Delhi: Business Horizon: 256.

21. Murray B. R., Baron E. J. and Pfaller M. A. (1995). Manual of Clinical Microbiology $6^{\text {th }}$ ed; Vol. 6, Washington DC: ASM Press, 156-208.

22. Okoye E.I. (2015). The effect of alkaloids and flavonoids extracts of Vitex doniana seed on some microorganisms. Int. J. Cancer, Clin. Invent. and Exper. Oncol., 1(1):19-23.

23. Sabahi M., Ramezanian M., Jaffari G., Heravi G. and Bahaeddini (1985). Survey of Iranian Plants for Saponins, Alkaloids, Flavonoids, and Tannins. IV. The Plants of Kerman Province,” Int. J. Crude Drug Res., 23(4): 165175.

24. Salleh B. and Sulaiman B. (1984). Fusaria associated with naturally diseased plants in Penang. J. Plant Prot. Trop., 1: 47-53.

25. SAS. (2012). Sas/Salt users guide for personal computers, release 7.0 Sas. Inst. Inc. Cry. New York.

26. Srikanth P., Sudharsanam S. and Steinberg R. (2008). Bio-aerosols in indoor environment: Composition, health effects, and analysis. Ind. J. Med. Microbiol., 26: 302-312.

27. Torssel K. B. (1997). Natural product chemistry (Amechanistic, biosynthetic and ecological approach), $2^{\text {nd }} \cdot A p$ otekarsocietten, kristianstads Boktryckeri: 480 pp.

28. Verma R., Chaurasia L. and Katiyar S. (2008). Potential antifungal plants for controlling building fungi. Nat Prod. Rad., 7: 374-387.

29. Wardah A. R., Hafizi R., Siti Nurdijati B. and Salleh B. (2011). Incidence and remediation of fungi in sick building in Malaysia-A case study. Aerobiologia. DOI: 10.1007/s 10453-09226-y.

30. Wink M. (1997). Special nitrogen metabolism. In: Dey, P. M. and Harborne, J.B. (Eds.), Plant biochemistry Academic press LLCC, Florida: 439- 486.

31. Zaidi M. A. and Crow Jr. S. A. (2005). Biologically active traditional medicinal herbs from Balochistan. Pak. J. Ethnopharmacol., 96: 331-334.

32. Zaidi M. A. and Crow Jr. S. A. (2012). Cytotoxicity of four medical plants of Pakistan. Pak. J. Bot., 44: 395 397.

33. Zaree R., Farhadi M., Mohammdzadeh Z. and Goudarzi G. R. (2013). Extraction and comparison of alkaloids in different organs during different phonological periods of Nitraria schoberi. Ann. Biologic. Res., 4 (2):130-135.

34. Zhu H., Phelan P.E., Duan T., Raupp G.B., Fernando H.J.S. and Che F. (2003). Experimental study of indoor and outdoor airborne bacterial concentration in Tempe, A, Arizona, USA. Aerobiologia, 19: 201-211. 